\title{
SCIDoC
}

\author{
International Journal of Dentistry and Oral Science (IJDOS) \\ ISSN: 2377-8075
}

\section{A Review of Three Dimensional Process Flow in Surgical Treatment Planning}

\author{
Research Article
}

\section{Shivangi Gaur ${ }^{1}$, Subhashini R ${ }^{1}$, M. Madhulaxmi² ${ }^{*}$ P.U. Abdul Wahab ${ }^{3}$}

${ }^{1}$ Post Graduate Student, Department of Oral and Maxillofacial Surgery, Saveetha Dental College and Hospitals, Saveetha Institute of Medical and Technical Sciences, Saveetha University, No 162, Poonamallee High Road, Vellappanchavadi, Chennai-600077, Tamil Nadu, India.

${ }^{2}$ Professor, Department of Oral and Maxillofacial Surgery, Saveetha Dental College and Hospitals, Saveetha Institute of Medical and Technical Sciences, Saveetha University, No 162, Poonamallee High Road, Vellappanchavadi, Chennai-600077, Tamil Nadu, India.

${ }^{3}$ Professor, Department of Oral and Maxillofacial Surgery, Saveetha Dental College and Hospitals, Saveetha Institute of Medical and Technical Sciences, Saveetha University, No 162, Poonamallee High Road, Vellappanchavadi, Chennai-600077, Tamil Nadu, India.

\section{Abstract}

Surgeons usually depend on their surgical training as well as medical imaging techniques such as magnetic resonance imaging (MRI) or computed tomography (CT) for the planning any surgical treatment process. Due to the anatomical complexity of the surgery site in head and neck region, $2 \mathrm{D}$ images are sometimes not sufficient to successfully analyze the structural details. In such cases a 3D printed model of the patient's anatomy enables customized preoperative planning. 3D printing technology is getting more and more attention especially in the craniofacial region. This article reviews the scope of this technology in maxillofacial surgery. 3D printing technology, also known as rapid prototyping or additive manufacturing or solid-freeform technology, was first demonstrated in the year 1986 [1]. Since then this technique has attracted significant attention, especially in maxillofacial surgery, due to the incredible ability to create complex constructs with highest possible precision. Reconstruction and rehabilitation using this technology offers precise and durable patient-specific models for various surgical applications.

Keywords: Rapid Prototyping; Additive Manufacturing; Surgical Planning; Preoperative Surgical Planning; 3D Printing.

\section{Introduction}

Surgeons usually face the challenging task of carrying out surgeries on complex anatomical structures in the head and neck region. Advances in medical imaging such as multi-detector computed tomography (MDCT) and magnetic resonance imaging (MRI) have made radiological diagnosis more informative and less invasive. MRI, CT and MDCT provide high resolution two-dimensional images, yet are constrained in their capacity to precisely delineate complex 3D structures.

3D reconstruction techniques offer a better understanding of structural complexity by allowing rotation and separation of layers in the 3D model.

\section{Applications}

Surgical applications of 3D technology can be listed as:

1. Acquiring accurate anatomic prototypes which ease preoperative planning and improve postoperative facial contour symmetry $[2,3]$.

2. Inspection of anatomy preoperatively, practice different surgical techniques and thereby reducing the operating time and minimizing errors $[4,19]$.

3. Virtually planning [5].

4. Printing pre-contoured grafts and plates to improve surgical outcomes [6].

5. 3D constructed prostheses $[7,8]$.

6. Cutting-edge simulation models to enhance surgical education [9].

\section{*Corresponding Author:}

Dr M. Madhulaxmi,

Reader, Department of Oral and Maxillofacial Surgery, Saveetha Dental College and Hospitals, Saveetha Institute of Medical and Technical Sciences, Saveetha University, No 162, Poonamallee High Road Vellappanchavadi, Chennai-600077 Tamil Nadu, India.

Tel: +91-73738-14000

E-mail: madhulaxmi11@gmail.com

Received: September 27, 2020

Accepted: October 06, 2020

Published: November 08, 2020

Citation: Shivangi Gaur, Subhashini R, M. Madhulaxmi, P.U. Abdul Wahab. A Review of Three Dimensional Process Flow in Surgical Treatment Planning Int J Dentistry Oral Sci. 2020;7(11):969-971. doi: http://dx.doi.org/10.19070/2377-8075-20000192

Copyright: M. Madhulaxmi 2020 . This is an open-access article distributed under the terms of the Creative Commons Attribution License, which permits unrestricted use, distribution and reproduction in any medium, provided the original author and source are credited. 
The concept of 3D printing can be summarized as $[10,11]$.

\begin{tabular}{|c|c|}
\hline \multicolumn{2}{|l|}{$\begin{array}{l}\text {-Magnetic Resonance Imaging (MRI) } \\
\text {-Computed Tomography (CT) }\end{array}$} \\
\hline \multicolumn{2}{|c|}{-File saved as DICOM format (Digital Imaging and Communications in Medicine) } \\
\hline \multicolumn{2}{|c|}{$\begin{array}{l}\text { - Computer Aided Design (CAD) software } \\
\text { - File converted to STL file (Standard Tessellation Language) }\end{array}$} \\
\hline \multicolumn{2}{|l|}{ - Virtual prototype model } \\
\hline -3D Printing technique choosing: & $\begin{array}{l}\text {-Fused deposition modelling (FDM) } \\
\text { - Stereolithographry (SLA) } \\
\text { - Selective laser sintering (SLS) } \\
\text { - Inkjet bioprinting } \\
\text {-Extrusision bioporinting } \\
\text {-Laser assisted bioprinting }\end{array}$ \\
\hline \multicolumn{2}{|c|}{ - Printing layer by layer to achieve the final structure } \\
\hline - Post production modification & \\
\hline
\end{tabular}

\section{Workflow}

The work flow behind 3D printing is summarized as $[12,14]$;

1. Capture anatomic structures using imaging techniques like magnetic resonance imaging (MRI) and computed tomography (CT) 2. Save the scan images in Digital Imaging and Communications in Medicine (DICOM) format

3. Use Computer-Aided Design (CAD) software to create a virtual 3D prototype

4. Use Standard Tessellation Language (STL) that allows for 3D printing

5. Select appropriate printing technique 20 like stereolithography (SLA), fused deposition modelling (FDM), selective laser sintering (SLS), bioprinting (laser-assisted, inkjet, extrusion)

6. Post-printing modification of the object to achieve final product.

\section{Materials Used}

Autogenous graft are considered as the gold standard for bone grafting as it has osteoinductive, osteoconductive and osteogenic properties [15]. Some disadvantages include donor-site morbidity, limited quantities, postoperative pain, resorption, wound infection, increased blood loss and prolonged anaesthesia time [16] as well as lack of delivering ideal geometry. Tissue engineering is hence a potential tool combining material science, engineering and biology to restore, replace or improve biological functions of the body.

Scores of biodegradable polymers have been investigated for maxillofacial defect repair including polyglycolic acid (PGA), polylactic acid (PLA) and copolymer of PGA and PLA (PLGA) [17]. This copolymer PLGA has osteoconductive properties in vivo and can be cleared by metabolic processes. When large PLGA prosthesis undergoes mechanical strain bulk degradation happens, releasing lactic acid and glycolic acid resulting in drop of $\mathrm{pH}$ and tissue loss [18]. Another polymer investigated for craniofacial reconstruction is poly ( $\varepsilon$-caprolactone) (PCL), it has good biocompatibility and mechanical properties.

Other materials used are poly (propylene fumarate) (PPF) poly- mer, mesenchymal stem cells on a polyamide/hydroxyapatite scaffold, PEEK (poly ether ether ketone) etc.

Successful 3D printing from radiologic images is a multidisciplinary science. Accurate anatomical models require close interaction between radiologists and physicians. In terms of its surgical application, there is a need to design randomised clinical trials that prove the advantages of adopting 3D planning over the classical surgical treatment planning. A possible limitation to use is the time needed to produce a 3D-printed model [19].

\section{Conclusion}

In synopsis, the use of additive manufacturing technology in oral and maxillofacial surgery has good potential and can be utilized for careful surgical treatment planning. The generation of custom made implants might will address the downsides of current treatment strategies by creation of exact prototypes for fitting in the defect. Patient specific implants can thereby transform research, treatment methodology, and educational streams of dentistry ameliorating oral health care. $3 \mathrm{D}$ printing has a high potential for education in all disciplines of surgery.

\section{References}

[1]. Choi JW, Kim N. Clinical application of three-dimensional printing technology in craniofacial plastic surgery. Archives of plastic surgery. 2015 May;42(3):267.Pubmed PMID: 26015880.

[2]. Marconi S, Pugliese L, Botti M, Peri A, Cavazzi E, Latteri S, et al. Value of 3D printing for the comprehension of surgical anatomy. SurgEndosc. 2017 Oct;31(10):4102-4110. PubmedPMID: 28281114.

[3]. Azuma M, Yanagawa T, Ishibashi-Kanno N, Uchida F, Ito T, Yamagata K, et al. Mandibular reconstruction using plates prebent to fit rapid prototyping 3-dimensional printing models ameliorates contour deformity. Head Face Med. 2014 Oct 23;10:45. PubmedPMID: 25338640.

[4]. Patel A, Levine J, Brecht L, Saadeh P, Hirsch DL. Digital technologies in mandibular pathology and reconstruction. Atlas Oral MaxillofacSurgClin North Am. 2012 Mar;20(1):95-106. PubmedPMID: 22365432.

[5]. Sieira Gil R, Roig AM, Obispo CA, Morla A, Pagès CM, Perez JL. Surgical planning and microvascular reconstruction of the mandible with a fibular flap using computer-aided design, rapid prototype modelling, and precontoured titanium reconstruction plates: a prospective study. $\mathrm{Br} J$ Oral Maxillofac Surg. 2015 Jan;53(1):49-53. PubmedPMID: 25305795.

[6]. Zimmerer RM, Ellis E 3rd, Aniceto GS, Schramm A, Wagner ME, Grant MP, et al. A prospective multicenter study to compare the precision of posttraumatic internal orbital reconstruction with standard preformed and individualized orbital implants. J Craniomaxillofac Surg. 2016 Sep;44(9):148597. PubmedPMID: 27519662.

[7]. Crafts TD, Ellsperman SE, Wannemuehler TJ, Bellicchi TD, Shipchandler TZ, Mantravadi AV. Three-Dimensional Printing and Its Applications in Otorhinolaryngology-Head and Neck Surgery. Otolaryngol Head Neck Surg. 2017 Jun;156(6):999-1010. PubmedPMID: 28421875.

[8]. Ledgerwood LG, Chao J, Tollefson TT. Prosthetic reconstruction of complicated auricular defects: use of a hybrid prosthetic fabrication technique. JAMA Facial PlastSurg 2014; 16(2): 153-154.Pubmed PMID:24311116.

[9]. Lichtenstein JT, Zeller AN, Lemound J, Lichtenstein TE, Rana M, Gellrich NC, et al. 3D-Printed Simulation Device for Orbital Surgery. J Surg Educ. 2017 Jan-Feb;74(1):2-8. Pubmed PMID: 27986443.

[10]. Mitsouras D, Liacouras P, Imanzadeh A, Giannopoulos AA, Cai T, Kumamaru KK, et al. Medical 3D printing for the radiologist. Radiographics. 2015 Nov 12;35(7):1965-88.Pubmed PMID:26562233.

[11]. Aldaadaa A, Owji N, Knowles J. Three-dimensional Printing in Maxillofacial Surgery: Hype versus Reality. J Tissue Eng. 2018 Apr 20;9:2041731418770909. PubmedPMID: 29774140.

[12]. Marro A, Bandukwala T, Mak W. Three-dimensional printing and medical imaging: a review of the methods and applications. CurrProblDiagnRadiol 2016; 45(1): 2-9.PubmedPMID: 26298798.

[13]. Rengier F, Mehndiratta A, von Tengg-Kobligk H, Zechmann CM, Unterhinninghofen R, Kauczor HU, et al. 3D printing based on imaging data: review of medical applications. Int J Comput Assist Radiol Surg. 2010 
Jul;5(4):335-41. PubmedPMID: 20467825.

[14]. Frame M, Huntley JS. Rapid prototyping in orthopaedic surgery: a user's guide. ScientificWorldJournal. 2012;2012:838575. PubmedPMID: 22666160.

[15]. Farré-Guasch E, Wolff J, Helder MN, Schulten EA, Forouzanfar T, KleinNulend J. Application of Additive Manufacturing in Oral and Maxillofacial Surgery. J Oral Maxillofac Surg. 2015 Dec;73(12):2408-18. PubmedPMID: 25966454.

[16]. Sharif F, Ur Rehman I, Muhammad N, MacNeil S. Dental materials for cleft palate repair. Mater SciEng C Mater Biol Appl. 2016 Apr 1;61:1018-28. PubmedPMID: 26838929.

[17]. Whitcombe MJ, Kirsch N, Nicholls IA. Molecular imprinting science and technology: a survey of the literature for the years 2004-2011. J MolRecognit. 2014 Jun;27(6):297-401. PubmedPMID: 24700625.
[18]. Xie XH, Wang XL, Zhang G, He YX, Leng Y, Tang TT, et al. Biofabrication of a PLGA-TCP-based porous bioactive bone substitute with sustained release of icaritin. J Tissue EngRegen Med. 2015 Aug;9(8):961-72. PubmedPMID: 23255530

[19]. Pedersen TH, Gysin J, Wegmann A, Osswald M, Ott SR, Theiler L, et al. A randomised, controlled trial evaluating a low cost, 3D-printed bronchoscopy simulator. Anaesthesia. 2017 Aug;72(8):1005-1009. PubmedPMID: 28603907.

[20]. Ionita CN, Mokin M, Varble N, Bednarek DR, Xiang J, Snyder KV, Siddiqui AH, Levy EI, Meng H, Rudin S. Challenges and limitations of patientspecific vascular phantom fabrication using $3 \mathrm{D}$ Polyjet printing. InMedical Imaging 2014: Biomedical Applications in Molecular, Structural, and Functional Imaging. International Society for Optics and Photonics.2014 Mar 13 ;9038: 90380M. 